\title{
Foot per Second Squared
}

National Cancer Institute

\section{Source}

National Cancer Institute. Foot per Second Squared. NCI Thesaurus. Code C68670.

A unit of linear acceleration based on the U.S. Customary and British Imperial systems unit of length and equal to 0.3048 meter per second per second. 